\title{
DISTRIBUTION OF ROOT SYSTEM AT APPLE CV. GRANNY SMITH GRAFTED ON DIFFERENT DWARFING ROOTSTOCKS
}

\author{
Viktor Gjamovski $^{{ }^{*}}$, Marjan Kiprijanovski², Tosho Arsov² \\ ${ }^{1}$ Institute of Agriculture, Ss. Cyril and Methodius University, Skopje, Republic of Macedonia \\ ${ }^{2}$ Faculty of Agricultural Sciences and Food, Ss. Cyril and Methodius University, \\ Skopje, Republic of Macedonia \\ e-mail: v.gjamovski@zeminst.edu.mk
}

\begin{abstract}
This paper analyses the distribution of root systems of nine dwarf apple rootstocks (M.9 T 984, M.9 T 337 , Jork 9, Mark 9, Budagowski 9, M.9 EMLA, Pajam 1, Pajam 2 and Supporter 4). All rootstocks were grafted with apple cultivar Granny Smith. The study was performed in the experimental orchard established in the Prespa region (Resen, R. Macedonia). The experimental orchard was established in 2004, with a planting distance $3.5 \mathrm{~m} \times 1.5 \mathrm{~m}$. At the end of the $7^{\text {th }}$ growing season following characteristics were evaluated: length and weight of the fine (fibrous) and coarse roots, and depth distribution of the root system. Among the evaluated rootstocks statistically significant differences in total length of the fine roots were not found. Between different rootstocks the results for total length of coarse roots showed more variability. In general, even $89 \%$ of the total length of root system belonged to fine roots, and the highest percentage (35\%) was located at depths of 20 to $40 \mathrm{~cm}$. Trees grafted on Mark 9 rootstock had the highest value for total root length, while the smallest values were registered on those grafted on Pajam 1 rootstock. Trees grafted on Supporter 4 rootstock had the greatest weight of the root system, while the smallest one was found on rootstock Budagowski 9.
\end{abstract}

Key words: apple; rootstocks; root system; depth distribution

\section{INTRODUCTION}

The root systems of fruit trees have a heredity-determined pattern. However, the some environmental factors like soil, climate, presence of a shallow hard rock or groundwater, as well as the cultural practices applied, can induce important changes in the root system distribution in soil [1-3].

Knowledge of the quantity, quality and distribution of roots is useful in agricultural production to provide information on the location of fertilizer application, tree spacing, intercrops, soil management and irrigation [4]. The development of root system is primarily affected by its origin (rootstock and variety combination), soil and climate conditions, and applied cultural practices. Atkinson et al. [5] and Atkinson [6] point out that the length of root systems of apples directly depends on the planting distance and the type of the rootstock.

According to Fante Júnior et al. [7] the assessment of such factors as the volume of soil explored, root length and root activity is a difficult task, and great difficulties are encountered in any sampling technique, including the time spent, limited information obtained and great variability of results. According to Vasconcelos et al. [8] a perfect method for evaluating roots does not exist because the suitability of a method for the evaluation of the root system depends on the in situ conditions.

The ratio between the tree root system and the aerial system in grown fruit trees is relatively constant within the same soil, regardless of the cultivar and rootstock. In general, the tree root is approximately $25-30 \%$ of the total tree mass in intensive orchards [9], and most of the roots are distrib- 
uted within the $25-100 \mathrm{~cm}$ depth in temperate climate and mineral soils [10].

According to De Silva et al. [11] the main component of the root system of trees are fine roots (diameter $<2 \mathrm{~mm}$ ) through which trees made the absorption of water and nutrients.

The objective of this study is to show the effects of various dwarfing apple rootstocks on distribution of the root system of Granny Smith apple cultivar under the specific conditions of the apple growing region of Prespa, South-Western Macedonia.

\section{MATERIAL AND METHODS}

The research was carried out in the experimental orchard located in the South-Western part of the Republic of Macedonia (Region of Lake Prespa). According to Scheffer's and Schachtschabel's classification, the soil is a texture class clay loamy soil, which is characterized by a very suitable texture. The root system distribution of the rootstocks M.9 T 984, M.9 T 337, Jork 9, Mark 9, Budagowski 9, M.9 EMLA, Pajam 1, Pajam 2 and Supporter 4 was evaluated using the scion cultivar Granny Smith. The trees were planted in 2004 at a spacing of $3.5 \mathrm{~m} \times 1.5 \mathrm{~m}$ and were trained to slender spindle system. The experiment has been arranged in randomized block design with four replications of five trees per plot. The orchard is equipped with drip irrigation system. The study was carried out in 2010 (the $7^{\text {th }}$ growing season). The development of root system, its length and weight was determined by digging of the model trees, according to the method of trench. From each different rootstock, 4 representative trees with similar vigor of the crown were selected. From each tree the digging of $1 / 4$ of the total predicted area of the root system, differently positioned, was done. The size of the trench was $1,25 \mathrm{~m} \times 0,75 \mathrm{~m}$, or a half of the distance between rows and a half of the distance between the trees. The distribution and development of the root system were followed at 3 different depths: from $0-20 \mathrm{~cm} ; 20-40 \mathrm{~cm}$ and $40-60$ $\mathrm{cm}$.

The differences between rootstocks were evaluated by ANOVA analysis through General Linear Model (GLM) procedure. After GLM analyses, post hoc comparison of means was calculated by LSD. Results were expressed at the $\mathrm{P}<0.05$ level of significance.

\section{RESULTS AND DISCUSSION}

In Table 1 and Figures 1 and 2, the data of the length and distribution of the root system in the evaluated rootstocks are given. By analyzing the data on the length and distribution of the root system in the evaluated rootstock (Table 1, Figure 1, Figure 2), it can be concluded that there were no statistically significant differences in the total length of the fine roots between the evaluated rootstocks. The largest length of the fine roots was recorded in the rootstock Mark $9(23947.2 \mathrm{~cm})$, and the lowest in the rootstock Pajam $1(15270.4 \mathrm{~cm})$. A greater variability between rootstocks was observed in the length of the coarse roots $(>3 \mathrm{~mm}$ ). The highest value for the total length of coarse roots was measured in the rootstock Supporter 4 $(3617.6 \mathrm{~cm})$. It was statistically significantly higher than in the rootstock Budagowski $9(1017.6 \mathrm{~cm})$.

Table 1. Length of the root system of different dwarfing rootstocks in Granny Smith apple trees (cm)

\begin{tabular}{|c|c|c|c|c|c|c|c|c|}
\hline \multirow{3}{*}{ Rootstock } & \multicolumn{8}{|c|}{ Soil depth (cm) } \\
\hline & \multicolumn{4}{|c|}{ Fine roots $(<3 \mathrm{~mm})$} & \multicolumn{4}{|c|}{ Coarse roots $(>3 \mathrm{~mm})$} \\
\hline & $0-20$ & $20-40$ & $40-60$ & Total & $0-20$ & $20-40$ & $40-60$ & Total \\
\hline M.9 T 984 & $6030.4^{\mathrm{b}}$ & $10273.6^{a}$ & $4584.0^{\mathrm{a}}$ & $20888.0^{\mathrm{a}}$ & $435.2^{\mathrm{cd}}$ & $1417.6^{\mathrm{ab}}$ & $600.0^{\mathrm{bc}}$ & $2452.8^{\mathrm{ab}}$ \\
\hline M.9 T 337 & $7814.4^{\mathrm{ab}}$ & $8009.6^{\mathrm{a}}$ & $5467.2^{\mathrm{a}}$ & $21291.2^{\mathrm{a}}$ & $1236.8^{a}$ & $1086.4^{\mathrm{ab}}$ & $577.6^{\mathrm{bc}}$ & $2900.8^{a}$ \\
\hline Jork 9 & $8785.6^{\mathrm{ab}}$ & $9433.6^{\mathrm{a}}$ & $5092.8^{\mathrm{a}}$ & $23312.0^{\mathrm{a}}$ & $1051.2^{\mathrm{abc}}$ & $1534.4^{\mathrm{ab}}$ & $489.6^{\mathrm{bc}}$ & $3075.2^{\mathrm{a}}$ \\
\hline Mark 9 & $12672.0^{\mathrm{a}}$ & $7363.2^{\mathrm{a}}$ & $3912.0^{\mathrm{a}}$ & $23947.2^{\mathrm{a}}$ & $1033.6^{\mathrm{abc}}$ & $1486.4^{\mathrm{ab}}$ & $486.4^{\mathrm{bc}}$ & $3006.4^{\mathrm{a}}$ \\
\hline Budagowski 9 & $5604.8^{\mathrm{b}}$ & $6124.8^{\mathrm{a}}$ & $4945.6^{\mathrm{a}}$ & $16675.2^{\mathrm{a}}$ & $280.0^{\mathrm{d}}$ & $560.0^{\mathrm{b}}$ & $177.6^{\mathrm{c}}$ & $1017.6^{\mathrm{b}}$ \\
\hline M.9 EMLA & $6812.8^{\mathrm{ab}}$ & $10088.0^{\mathrm{a}}$ & $5756.8^{\mathrm{a}}$ & $22657.6^{\mathrm{a}}$ & $484.8^{\mathrm{bcd}}$ & $1200.0^{\mathrm{ab}}$ & $1403.2^{\mathrm{a}}$ & $3088.0^{\mathrm{a}}$ \\
\hline Pajam 1 & $5044.8^{\mathrm{b}}$ & $5843.2^{\mathrm{a}}$ & $4382.4^{\mathrm{a}}$ & $15270.4^{\mathrm{a}}$ & $529.6^{\text {bcd }}$ & $708.8^{\mathrm{ab}}$ & $1115.2^{\mathrm{ab}}$ & $2353.6^{\mathrm{ab}}$ \\
\hline Pajam 2 & $5926.4^{\mathrm{b}}$ & $6585.6^{\mathrm{a}}$ & $4611.2^{\mathrm{a}}$ & $17123.2^{\mathrm{a}}$ & $667.2^{\mathrm{abcd}}$ & $1489.6^{\mathrm{ab}}$ & $737.6^{\mathrm{abc}}$ & $2894.4^{\mathrm{a}}$ \\
\hline Supporter 4 & $8166.4^{\mathrm{ab}}$ & $8216.0^{\mathrm{a}}$ & $6171.2^{\mathrm{a}}$ & $22553.6^{\mathrm{a}}$ & $1110.4^{\mathrm{ab}}$ & $1640.0^{\mathrm{a}}$ & $867.2^{\mathrm{abc}}$ & $3617.6^{\mathrm{a}}$ \\
\hline Average & 7428.6 & 7993.1 & 4991.5 & 20413.2 & 435.2 & 1417.6 & 600.0 & 2452.8 \\
\hline
\end{tabular}

Values followed by the same letter in a column were not statistically different according to LSD test $(\mathrm{P}<0.05)$. 
In all the examined rootstocks, the largest length of the fine and coarse roots was recorded at a depth of 20 to $40 \mathrm{~cm}$, with average values of 7993.1 $\mathrm{cm}$, and $1417.6 \mathrm{~cm}$, respectively. It is in line with the results of Arsov [11] who examined the distribution of the roots of the Jonagold apple variety grafted on M9 rootstock.
An exception to this statement is the data for the fine roots of the Mark 9 rootstock. The root length at the depth from 0 to $20 \mathrm{~cm}$ was greater in relation to the length at the depth from 20 to $40 \mathrm{~cm}$ (Figure 1). These data correlated with literature data that indicate a shallow development of the root of this rootstock and its susceptibility to drought.

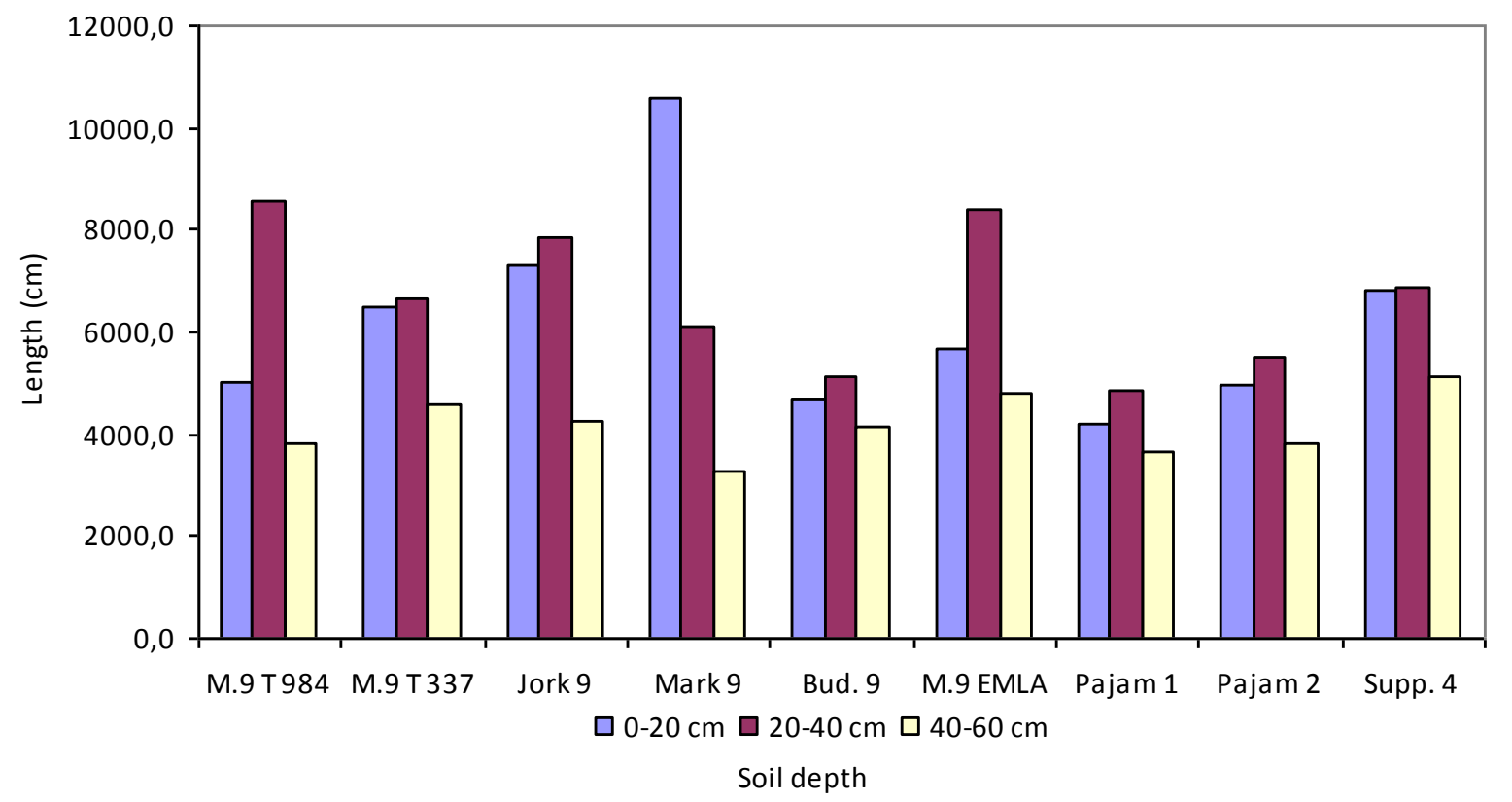

Figure 1. Vertical distribution of the fine roots of different dwarfing rootstocks in Granny Smith apple trees

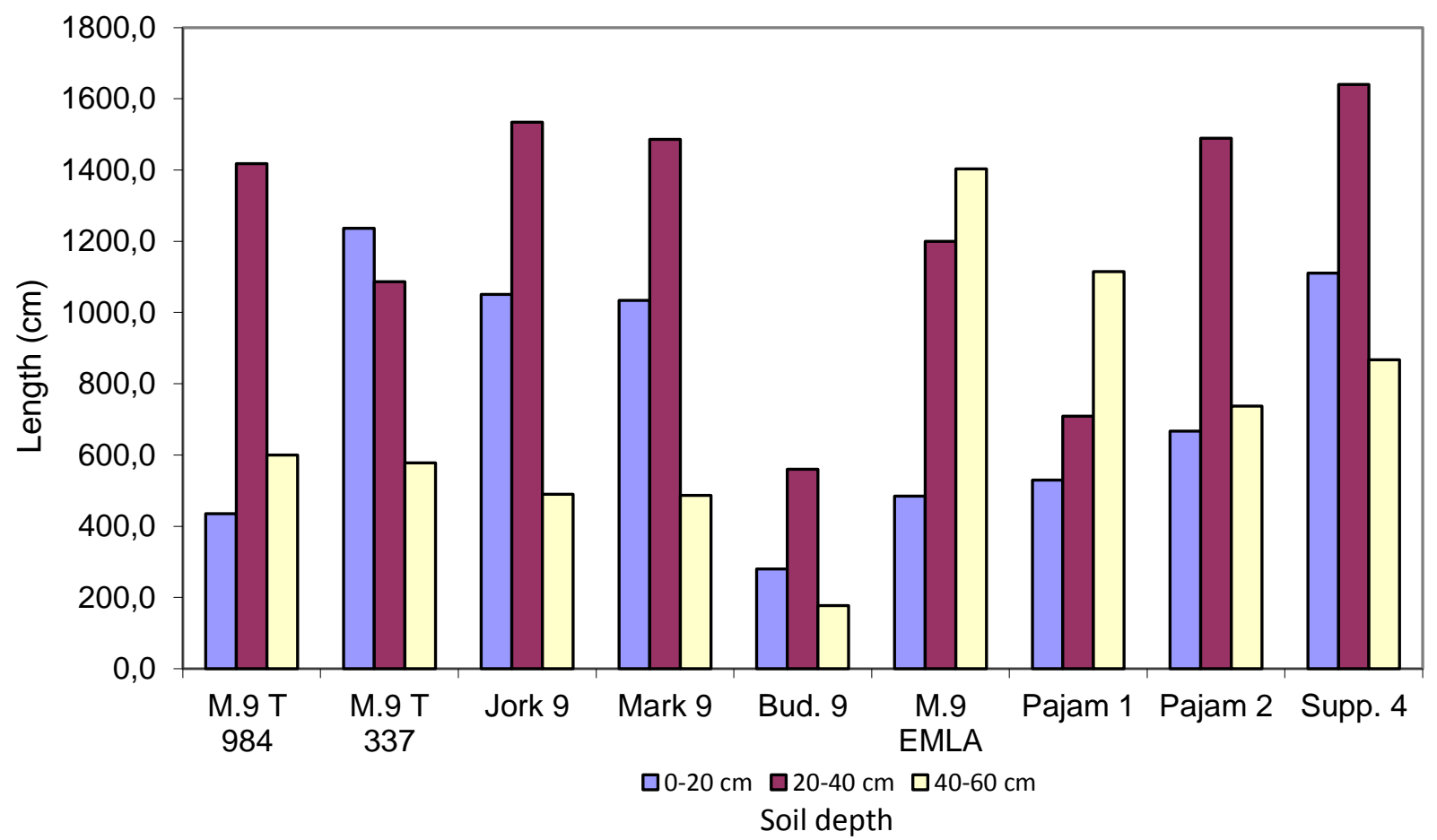

Figure 2. Vertical distribution of the coarse roots of different dwarfing rootstocks in Granny Smith apple trees 
According to the data on distribution of different types of roots in different soil depths (Figure 3 ), it can be concluded that even $89 \%$ of the total length of the root system belongs to the fine roots and the largest percentage of them $(35 \%)$ was located at a soil depth of 20 to $40 \mathrm{~cm}$.

The data on the weight of the fine and coarse roots of the evaluated rootstocks, depending on the depth of the soil layer are given in Table 2. In all evaluated rootstocks the highest weight of the fine roots was registered at soil depths between 20 and $40 \mathrm{~cm}$, except in the rootstock Mark 9 where weight of the fine roots in the first soil layer was higher. The highest total weight of the fine roots was found in Jork 9 rootstok (347.9 g), while the smallest one was found in Pajam 1 rootstok (182.3 g). Statistically significant differences between the rootstocks concerning the total weight of the fine root were not detected.

Expectedly, the highest weight of the coarse roots in all evaluated rootstocks was found at the depth of the soil layer from 0 to $20 \mathrm{~cm}$, which on average was $349.8 \mathrm{~g}$. According to the total values, the Supporter 4 rootstock had the highest weight of coarse roots (1344.4 g), statistically significantly higher than those in the Budagowski 9 rootstock, which had the lowest value $(146,7 \mathrm{~g})$ for this parameter.

According to Arsov [12], the total weight of the fine roots in M9 rootstock grafted with Jonagold apple variety growth on the planting distance of $4 \times 1.5 \mathrm{~m}$ was $573.6 \mathrm{~g}$, and of the coarse roots it was $2397.4 \mathrm{~g}$. This data correlates with the data obtained in this research.

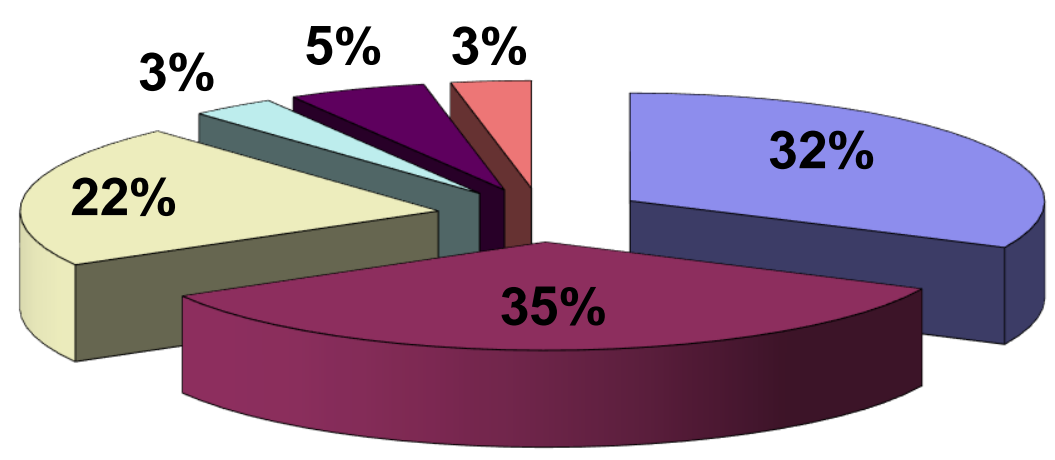

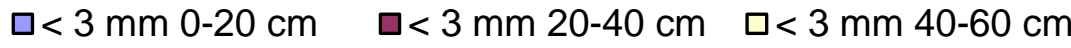

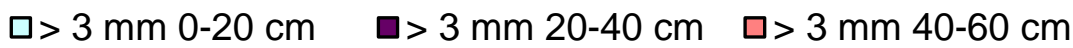

Figure 3. Length and depth distribution of total root system on various dwarfing apple rootstocks in Granny Smith apple trees

Table 2. Weight of the root system of different dwarfing rootstocks in Granny Smith apple trees (g)

\begin{tabular}{|c|c|c|c|c|c|c|c|c|}
\hline \multirow{3}{*}{ Rootstock } & \multicolumn{4}{|c|}{ Fine roots $(<3 \mathrm{~mm})$} & \multicolumn{4}{|c|}{ Coarse roots $(>3 \mathrm{~mm})$} \\
\hline & \multicolumn{8}{|c|}{ Soil depth (cm) } \\
\hline & $0-20$ & $20-40$ & $40-60$ & Total & $0-20$ & $20-40$ & $40-60$ & Total \\
\hline M.9 T 984 & $89.4^{\mathrm{ab}}$ & $148.5^{\mathrm{a}}$ & $52.3^{\mathrm{a}}$ & $290.2^{\mathrm{a}}$ & $148.2^{\mathrm{b}}$ & $333.8^{\mathrm{a}}$ & $124.2^{\mathrm{abc}}$ & $606.2^{\mathrm{ab}}$ \\
\hline M.9 T 337 & $108.5^{\mathrm{ab}}$ & $128.2^{\mathrm{a}}$ & $67.1^{\mathrm{a}}$ & $303.7^{\mathrm{a}}$ & $737.0^{\mathrm{a}}$ & $351.1^{\mathrm{a}}$ & $65.7^{\mathrm{bc}}$ & $1153.7^{\mathrm{a}}$ \\
\hline Jork 9 & $136.6^{\mathrm{ab}}$ & $151.0^{\mathrm{a}}$ & $60.3^{\mathrm{a}}$ & $347.8^{\mathrm{a}}$ & $253.6^{\mathrm{ab}}$ & $436.0^{\mathrm{a}}$ & $56.9^{\mathrm{bc}}$ & $746.6^{\mathrm{ab}}$ \\
\hline Mark 9 & $165.1^{\mathrm{a}}$ & $105.0^{\mathrm{a}}$ & $40.7^{\mathrm{a}}$ & $310.7^{\mathrm{a}}$ & $276.4^{\mathrm{ab}}$ & $308.8^{\mathrm{a}}$ & $87.5^{\mathrm{bc}}$ & $672.7^{\mathrm{ab}}$ \\
\hline Budagowski 9 & $60.7^{\mathrm{b}}$ & $93.0^{\mathrm{a}}$ & $42.5^{\mathrm{a}}$ & $196.1^{\mathrm{a}}$ & $96.0^{\mathrm{ab}}$ & $32.7^{\mathrm{b}}$ & $17.9^{c}$ & $146.7^{\mathrm{b}}$ \\
\hline M.9 EMLA & $89.6^{\mathrm{ab}}$ & $126.7^{\mathrm{a}}$ & $75.2^{\mathrm{a}}$ & $291.5^{\mathrm{a}}$ & $98.1^{\mathrm{b}}$ & $333.2^{\mathrm{a}}$ & $276.7^{a}$ & $708.0^{\mathrm{ab}}$ \\
\hline Pajam 1 & $52.9^{\mathrm{b}}$ & $63.9^{\mathrm{a}}$ & $65.5^{\mathrm{a}}$ & $182.3^{\mathrm{a}}$ & $345.8^{\mathrm{ab}}$ & $173.7^{\mathrm{a}}$ & $184.1^{\mathrm{abc}}$ & $703.7^{\mathrm{ab}}$ \\
\hline Pajam 2 & $84.2^{\mathrm{ab}}$ & $102.9^{\mathrm{a}}$ & $67.9^{\mathrm{a}}$ & $255.0^{\mathrm{a}}$ & $509.3^{\mathrm{ab}}$ & $451.6^{\mathrm{a}}$ & $188.2^{\mathrm{abc}}$ & $1149.1^{\mathrm{a}}$ \\
\hline Supporter 4 & $120.7^{\mathrm{ab}}$ & $112.9^{\mathrm{a}}$ & $75.4^{\mathrm{a}}$ & $309.0^{\mathrm{a}}$ & $683.7^{\mathrm{a}}$ & $456.3^{\mathrm{a}}$ & $204.4^{\mathrm{ab}}$ & $1344.4^{\mathrm{a}}$ \\
\hline Average & 100.9 & 114.7 & 60.7 & 276.3 & 349.8 & 319.7 & 133.9 & 803.4 \\
\hline
\end{tabular}

Values followed by the same letter in a column were not statistically different according to LSD test (P < 0.05$)$. 


\section{CONCLUSIONS}

The mass and the length of the root system, and its horizontal and vertical layout are important elements in determining the planting distance, as well as for applying agro-technical measures in the orchard.

Between the nine economically most important rootstocks evaluated in Prespa region statistically significant differences were not found. The highest root length in all investigated rootstocks was found at the soil depths between 20 and $40 \mathrm{~cm}$. An exception to this is the root system of the trees on Mark 9 rootstock where the highest length was found at the first soil depth $(0-20 \mathrm{~cm})$. Total root lengths were the highest in the trees on Mark 9, Supporter 4 and Jork 9 rootstocks, while the lowest values were registered in the trees on Pajam 1 and Budagowski 9 rootstocks. The trees grafted on Supporter 4 had the highest weight of coarse roots, while the lowest one was found in the trees grafted on Budagowski 9 rootstock.

\section{REFERENCES}

[1] V. A. Kolesnikov, The Root System of Fruit Plants, WASCHNIL Press, Moscow, 1971.

[2] O. Tudosescu, P. Parnia, Tree root architecture depending on rootstock and cultivar in apple (in Romanian), Lucr. St. ICPP, II, Pitesti, Romania, (1975), pp. 189-200.

[3] S. Stan, M. Cotorobai, Influence of growth regulators on tree rooting system in apple (in Romanian),
Lucr. St. ICPP, X, Pitesti, Romania, (1983), pp. 137-142.

[4] A. A. Fracaro, F. M. Pereira, Distribuição do sistema radicular da goiabeira 'Rica' produzida a partir de estaquia herbácea, Revista Brasileira de Fruticultura, v. 26, n. 1 (2004), pp. 183-195.

[5] D. Atkinson, D. Naylor, G. A. Coldrick, The effect of tree spacing on the apple root system, Horticulture Research, 16 (1976), pp. 89-105.

[6] D. Atkinson, The Distribution and Effectiveness of the Roots of Tree Crops, Hort. Rev., 2, (1980), pp. 424-490.

[7] L. Fante Junior, K. Reichardt, L. A. C. Jorge, S. Crestana, Distribuição do sistema radicular do milho em terra roxa estruturada latossólica: I. Comparação de metodologias, Scientia Agricola, v. 51, n. 3 (1994), pp. 513-518.

[8] A. C. M. Vasconcelos, A. A. Casagrande, D. Perecin, L. A. C. Jorge, M. G. A. Landell, Avaliação do sistema radicular da cana-de-açúcar por diferentes métodos, Revista Brasileira de Ciência do Solo, v. 27, n. 3, (2003), pp. 849-858.

[9] M. M. Westerwood, Temperate-Zone Pomology, Freeman \& Company, W. H., 1978, New York.

[10] A. Negrila, Pomology, Didactica si Pedagogica, Bucharest, 1971.

[11] N. De Silva, A. J. Hall, D. S. Tustin, P. W. Gandar, Analysis of distribution of root length density of apple trees on different dwarfing rootstocks, Annals of Botany, 83 (1999), pp. 335-345.

[12] T. Arsov, Intensive systems in apple growing, $\mathrm{PhD}$, Ss. Cyril and Methodius University Skopje, Faculty of Agricultural Science and Food, (2009), p. 94.

\title{
ДИСТРИБУЦИЈА НА КОРНОВИОТ СИСТЕМ КАЈ СОРТАТА ЈАБОЛКО ГРЕНИ СМИТ КАЛЕМЕНА НА РАЗЛИЧНИ СЛАБОБУЈНИ ПОДЛОГИ
}

\author{
Виктор Ѓамовски ${ }^{1 *}$, Марјан Кипријановски ${ }^{2}$, Тошо Арсов \\ 1Земјоделски институт, Универзитет „Св. Кирил и Методиј“, Скопје, Република Македонија \\ Факултет за земјоделски науки и храна, Универзитет „Св. Кирил и Методиј“, \\ Скопје, Република Македонија,
}

Во трудот се содржани резултатите од споредбени испитувања на девет слабобујни подлоги за јаболко (M.9 T 984, M.9 T 337, Jork 9, Mark 9, Budagowski 9, M.9 EMLA, Pajam 1, Pajam 2 и Supporter 4), калемени на сортата грени смит, во однос на развојот и дистрибуцијата на кореновиот систем. Испитувањата се извршени во 7-та вегетациска година на овошките во експериментален овоштарник лоциран во регион на Преспа во Р Македонија. Овоштарникот е подигнат во 2004 година, со садење на овошките на растојание од $3,5 \mathrm{~m} \times 1,5 \mathrm{~m}$. Беа евалуирани следните карактеристики: должина и тежина на обрастувачките (влакнести) и скелетните коренчиња и дистрибуција по длабочина на кореновиот систем. Анализирајќи ги добиените податоци, заклучуваме дека помеѓу испитуваните подлоги не постојат статистички разлики во вкупната должина на обрастувачките коренчиња. Во резултатите за вкупна должина на скелетните коренчиња е забележана поголема варијабилност меѓу подлогите. Во принцип дури 89\% од вкупната должина на кореновиот систем 
отпаѓa на обрастувачките коренчиња, а највисокиот процент (35\%) коренчиња се наоѓаат на длабочина од 20 до $40 \mathrm{~cm}$. Овошките на подлогата Mark 9 имаат највисока вредност на вкупната должина на коренот, а најмалата оние кои се пресадени на Рајаm 1. Овошките на подлогата Supporter 4 имаат најголема тежина на кореновиот систем, додека најмала тежина имаат тие на Budagowski 9.

Клучни зборови: јаболко; подлога; коренов систем; дистрибуција на корен 